\title{
DISPARATE REGULATION OF INTERLEUKIN 8 GENE EXPRESSION FROM BLOOD MONOCYTES, ENDOTHELIAL CELLS, AND FIBROBLASTS BY INTERLEUKIN 4
}

\author{
T.J. Standiford, R.M. Strieter, K. Kasahara*, and S.L. Kunkel* \\ Division of Pulmonary and Critical Care Medicine, Departments of Internal Medicine \\ and *Pathology, University of Michigan, Ann Arbor, Michigan
}

Received Ju1y 24, 1990

The role(s) of novel chemotactic cytokines as mediators in the pathogenesis of many acute and chronic disease states is becoming increasingly apparent. One of these cytokines, interleukin 8 , is a product of both immune and non-immune cells. In this manuscript, we describe the suppression of IL-8 gene expression from stimulated monocytes by IL-4, while IL-4 had no suppressive effects on IL-8 gene expression from stimulated fibroblasts and endothelial cells. Our data suggest that IL-4 may function as an endogenous regulator of monocyte cytokine expression, including the chemotactic cytokine IL-8. 1990 Academic Press, Inc.

The tissue-specific sequestration of neutrophils is a halimark of many acute inflammatory disease states. Factors that mediate directed neutrophil migration in vivo remain unknown. Interleukin 8 (IL-8) is a recently described polypeptide with potent neutrophil activating and chemotactic activity $(1,2)$. In the presence of an exogenous stimulus such as lipopolysaccharide (LPS), IL-8 is expressed from immune cells, including peripheral blood monocytes and tissue macrophages, and nonimmune cells such as endothelial cells $(1,3,4)$. Fibroblasts and epithelial cells also produce IL-8, but only after stimulation with the macrophage-derived cytokines tumor necrosis factor (TNF) and interleukin 1 (IL-1) $(5,6)$. Hence, the mononuclear phagocyte may play a critically important role in neutrophil recruitment either by generating $\mathrm{IL}-8$ or by inducing the expression of $\mathrm{LL}-8$ from surrounding non-immune cells via the production of TNF and IL-1.

Though many of the cellular sources and biologic activities of IL-8 have recently been described, little is known about the regulation of IL- 8 gene expression. Interleukin 4 (IL-4), a $20 \mathrm{kD}$ glycoprotein expressed from $\mathrm{T}$ lymphocytes, has been shown to have important immunoregulatory activities on both lymphocytes and mononuclear phagocytes (7). While IL-4 generally up-regulates a number of $B$ and T cell functions, this cytokine has been shown to inhibit several monocyte/macrophage

Abbreviations used in this manuscript: IL-4, interleukin 4; IL-8, interleukin 8; TNF, tumor necrosis factor; IL-1b, interleukin 1-beta; LPS, lipopolysaccharide. 
activities including macrophage colony formation, hydrogen peroxide production, and the expression of TNF, IL-1, and prostaglandin $E_{2}$ (8-10). We now describe the disparate regulation of IL- 8 gene expression by IL-4, as IL-4 causes substantial suppression of monocyte-derived IL-8 mRNA, while having no effect on IL-8 gene expression from the non-immune cells fibroblasts and endothelial cells. By inhibiting the generation of chemotactic or inflammatory cytokines from mononuclear phagocytes, IL-4 may play an important role in the endogenous modulation of an inflammatory response.

\section{MATERIALS AND METHODS}

Cell Preparations: Human monocytes were obtained from venous blood from healthy volunteers by ficoll-hypaque centrifugation and purified by adherence to plastic for 1 hr. The monocytes were $>95 \%$ viable as determined by trypan blue exclusion. Human endothelial cells were isolated from umbilical veins as previously described (4). The recovered endothelial cells were cultured in medium 199 supplemented with $100 \mathrm{ug} / \mathrm{ml}$ endothelial cell growth supplement, $20 \%$ fetal bovine serum, and $100 \mathrm{ug} / \mathrm{ml}$ bovine lung heparin. All cells in these studies were used prior to the fifth passage in culture. Primary human foreskin fibroblasts (4-8 passages) were grown to confluency in RPMI 1640 containing $1 \mathrm{nM}$ glutamine, $25 \mathrm{nM}$ HEPES, 100 units/ml penicillin, 100 units $/ \mathrm{ml}$ streptomycin, plus $10 \%$ fetal calf serum. On the day of use, cells were washed free of serum and either cytokines or LPS were added for specific times and doses.

Reagents: Human recombinant IL- $1 \beta$ with a specific activity of $30 \mathrm{U} / \mathrm{ng}$ was the generous gift of the Upjohn Company. Human recombinant TNF- $\alpha$ with a specific activity of $22 \mathrm{U} / \mathrm{ng}$ was a gift of the Cetus Corporation. LPS $(0111 ; \mathrm{B} 4)$ was purchased from Sigma (St. Louis, MO.). Human recombinant IL-4 was purchased from R\&D Systems (Minneapolis, MN.).

Northern Blot Analysis: Total cellular RNA from blood monocytes, endothelial cells, or fibroblasts was isolated using a modification of Chirgwin et al. (11). Briefly, monolayers were overlaid with $1-3 \mathrm{ml}$ of a solution consisting of $25 \mathrm{mM}$ Tris, $\mathrm{pH} 8.0$, containing 4.2 M guanidine isothiocyanate, $0.5 \%$ Sarkosyl, and $0.1 \mathrm{M} 2$ mercaptoethanol. After homogenization, the above suspension was added to an equal volume of $100 \mathrm{mM}$ Tris, $\mathrm{pH} 8.0$, containing $10 \mathrm{mM}$ EDTA and $1.0 \%$ sodium dodecyl sulfate. The mixture was then extracted with cholorform-phenol and chlorform-isoamyl alcohol. The RNA was alcohol-precipitated and the pellet dissolved in $10 \mathrm{mM}$ Tris, $0.1 \mathrm{mM}$ EDTA (TE) buffer with $0.1 \%$ Sarkosyl. RNA was separated by Northern blot analysis using formaldehyde, $1 \%$ agarose gels, transblotted to nitrocellulose, baked, prehybridized and hybridized with a $32 \mathrm{P} 5$-end labeled oligonucleotide probe. The 30 mer oligonucleotide probe was complementary to nucleotides 262-291 and had the sequence 5'-GTT-GGC-GCA-GTG-TGG-TCC-ACTCTC-AAT-CAC-3' (2). Blots were washed and autoradiographs were quantitated using laser densitometry (Ultrascan XS, LXB Instruments, INC., Houston, TX) Equivalent amounts of total RNA/gel were assessed by monitoring $28 \mathrm{~s}$ and $18 \mathrm{~s}$ rRNA.

\section{RESULTS}

Suppression of IL-8 mRNA Expression from Monocytes by IL-4. To assess the effects of IL-4 on IL-8 gene expression from mononuclear phagocytes, monocytes were treated with graded doses of IL-4 from $100 \mathrm{pg} / \mathrm{ml}$ to $100 \mathrm{ng} / \mathrm{ml}$ in the presence and absence of LPS $(50 \mathrm{ng} / \mathrm{ml})$. While IL-4 treatment alone did not alter IL- 8 mRNA levels 
A
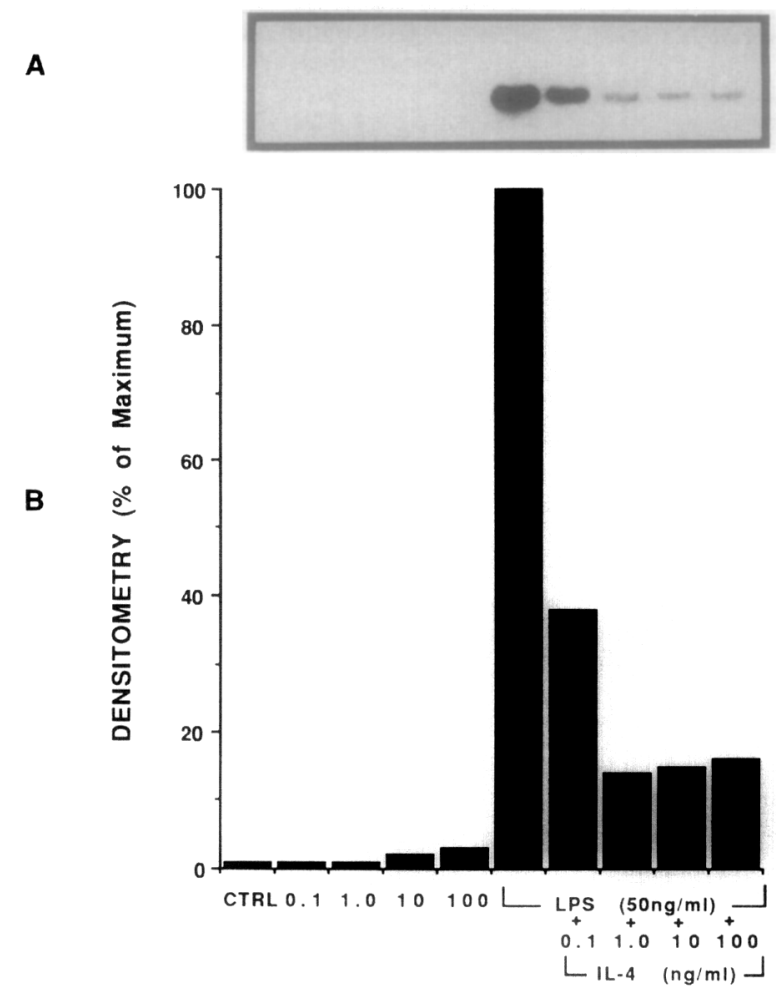

C

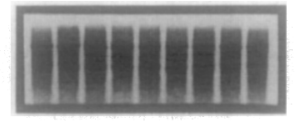

Figure 1 Dose-dependent suppression of IL-8 mRNA levels from stimulated blood monocytes by IL-4 $(0.1 \mathrm{ng} / \mathrm{ml}$ to $100 \mathrm{ng} / \mathrm{ml})$. Northern blot analysis demonstrating steady-state IL-8 mRNA levels (A), respective laser densitometry expressed as percent of maximum response (B), and $28 \mathrm{~s}$ and $18 \mathrm{~s}$ ribosomal RNA reflecting equal loading of RNA (C). Monocytes were treated with graded doses of IL-4 in the presence and absence of LPS $(50 \mathrm{ng} / \mathrm{ml})$.

from unstimulated monocytes, IL-4 caused a dose-dependent reduction in IL-8 mRNA levels from LPS-stimulated monocytes (figure 1). Suppression of IL-8 gene expression was seen at IL-4 concentrations as low as $100 \mathrm{pg} / \mathrm{ml}$, with an $85 \%$ reduction in IL-8 mRNA levels occurring at IL-4 concentrations of $1 \mathrm{ng} / \mathrm{ml}$ and above. IL-4 similarly reduced IL- 8 steady state mRNA from TNF and IL-1 $\beta$ stimulated blood monocytes (data not shown).

Effect of IL-4 on IL-8 Gene Expression from Endothelial Cells. Having demonstrated profound suppression of monocyte-derived IL-8 mRNA levels from stimulated monocytes, we designed experiments to assess the effects of IL-4 on IL- 8 gene expression from the non-immune cells endothelial cells and fibroblasts. Endothelial cells were treated with various concentrations of IL-4 with or without the primary stimulus IL-1 $\beta$. As seen in figure 2, IL-4 alone had no effect on IL-8 mRNA levels from these cells. In contrast to blood monocytes, IL-4 failed to have inhibitory effects on IL-8 gene expression from IL-1 $\beta$-stimulated $(2 \mathrm{ng} / \mathrm{ml})$ endothelial cells, even at 
A

A

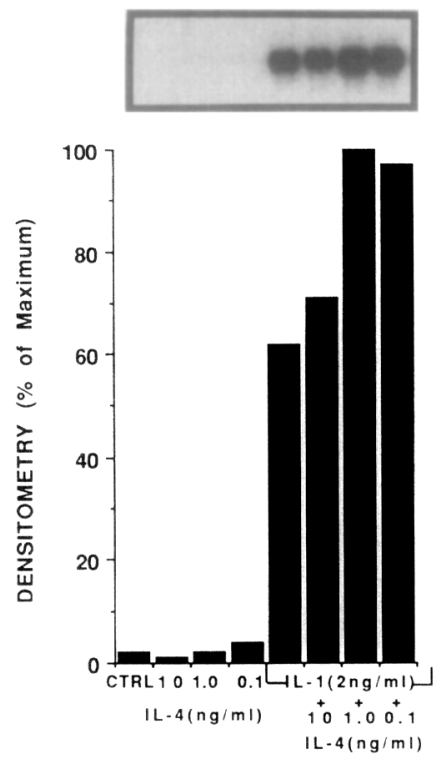

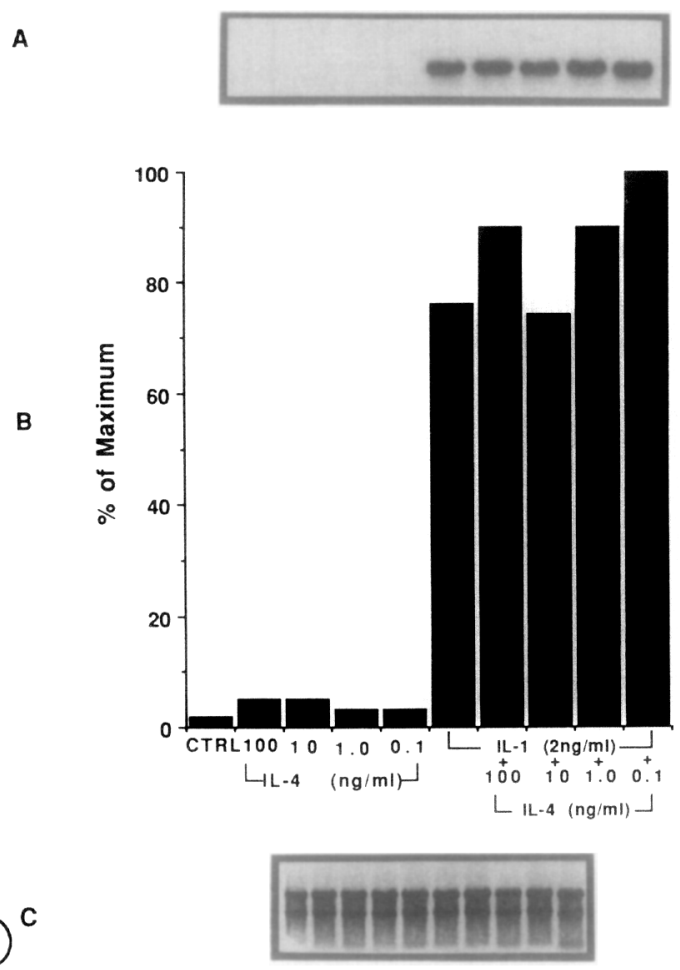

Eiqure 2. Failure of IL-4 $(0.1 \mathrm{ng} / \mathrm{ml}$ to $10 \mathrm{ng} / \mathrm{ml})$ to suppress $\mathrm{IL}-1 \beta$-induced $\mathrm{IL}-8$ gene expression from stimulated endothelial cells. Northern blot analysis depicting steadystate IL-8 mRNA levels (A), respective laser densitometry (B), and $28 \mathrm{~s}$ and 18s rRNA (C). Endothelial cells were treated with various concentrations of IL-4 with or without IL-1 $\beta(2 \mathrm{ng} / \mathrm{ml})$.

Figure 3. Failure of IL-4 $(0.1 \mathrm{ng} / \mathrm{ml}$ to $100 \mathrm{ng} / \mathrm{ml})$ to suppress $\mathrm{IL}-1 \beta$-induced $\mathrm{IL}-8$ gene expression from stimulated fibroblasts. Northern blot analysis depicting steadystate IL-8 mRNA levels (A), respective laser densitometry (B), and $28 \mathrm{~s}$ and $18 \mathrm{~s}$ rRNA(C). Fibroblasts were treated with various concentrations of IL-4 in the presence or absence of IL-1 $\beta(2 \mathrm{ng} / \mathrm{ml})$.

concentrations of IL-4 as high as $100 \mathrm{ng} / \mathrm{ml}$. In addition, IL-4 did not alter endothelial cell-derived IL-8 mRNA levels post stimulation with either TNF or LPS (data not shown).

Effect of IL-4 on IL-8 Gene Expression from Fibroblasts. Fibroblasts were treated with graded doses of IL-4 in the presence and absence of IL-1 $\beta(2 \mathrm{ng} / \mathrm{ml})$. As observed with endothelial cells, IL-4 had no effect on IL- 8 gene expression from unstimulated and IL$1 \beta$-stimulated fibroblasts (figure 3 ). Furthermore, IL-4 failed to suppress IL- 8 mRNA levels from fibroblasts when TNF was used as a primary stimulus (data not shown).

\section{DISCUSSION}

Neutrophil recruitment is a complex process that requires the elaboration of chemotactic factors in a precise and highly-regulated fashion. IL-8 may be an 
important mediator of selective neutrophil accumulation in several disease states, such as Adult Respiratory Distress Syndrome, ischemia-reperfusion injury, and autoimmune disease. The blood monocyte appears to be a major cellular source of IL-8 (1). In addition, blood monocytes produce large amounts of TNF and IL-1, cytokines which can induce IL-8 expression from fibroblasts, endothelial and epithelial cells (4-6). Hence, the regulation of monocyte-derived cytokines may be critically important in determining the extent of an inflammatory response to injury. While TNF and IL-1 expression from monocytes are tightly regulated by endogenous and exogenous mediators such as $\mathrm{PGE}_{2}$ and dexamethasone $(12,13)$, the production of IL-8 from blood monocytes does not appear to be significantly altered by these mediators.

We now describe the profound suppression of IL-8 mRNA from stimulated monocytes by the T-cell product IL-4, whereas IL-4 has no inhibitory effects an IL-8 gene expression from fibroblasts or endothelial cells. We have recently demonstrated that IL-4 suppresses both the gene expression and synthesis of immunoreactive IL-8 from blood mononuclear cells (14). The IL-4-induced suppression of IL-8 mRNA was dependent on de novo protein, as cycloheximide abrogated the inhibitory effect of IL-4. The mechanism(s) by which IL-4 disparately regulates monocytes as compared to non-immune cells remains unclear. IL-4 does not appear to induce a transferable inhibitory factor from blood monocytes, as treatment of fibroblasts with IL-4-treated monocyte-conditioned media failed to suppress IL-8 mRNA levels (data not shown). While IL-4 does not directly inhibit IL-8 gene expression from fibroblasts and endothelial cells, this cytokine can modulate the elaboration of IL-8 via the suppression of the host-generated signals TNF and IL-1. Our findings suggest that IL4 may function in vivo as an important endogenous antiinflammatory polypeptide.

Acknowledgments: This work was supported in part by Michigan Pheonix Memorial Research Grant and National Institutes of Health grants HL102401, HL31693, HL35276, and DK38149. Dr. Kunkel is an established investigator of the American Heart Association.

\section{REFERENCES}

1. Yoshimura, T., Matsushima, K., Oppenheim, J.J., and Leonard, E.J. (1987). J. Immunol. 139: 788-793.

2. Baggiolini, M., Walz, A. and Kunkel, S.L. (1989). J. Clin. Invest. 84: 1045-1049.

3. Strieter, R.M., Chensue, S.W., Basha, M.A., Standiford, T.J., Lynch, J.P., III, Baggiolini, M, and Kunkel, S.L. (1990). Am J Respir Cell Mol Biol 2: 321-325.

4. Strieter, R.M., Kunkel, S.L., Showell, H.J., Remick, D.G., Phan, S.H., Ward, P.A., and Marks, R.M. (1989). Science 243: 1467-1469.

5. Strieter, R.M., Phan, S.H., Showell, H.J., Remick, D.R., Lynch, J.P. , Genord, M., Raiford, C., Eskandari, M., Marks, R.M., and Kunkel, S.L. (1989). J. Biol. Chem. 264: $10621-10626$.

6. Elner, V.M., Strieter, R.M., Elner, S.G., Baggiolini, M., Lindley, I, and Kunkel, S.L. (1990). Am. J. Pathol. 136: 745-50.

7. Paul, P.E. and Ohara, J. (1987). Ann. Rev. Immunol. 5: 429-450. 
8. Jansesn, J.H., Wientjens, G.H., Fibbe, W.E., Willemze, R., and Kluin-Nelemans. (1989). J. Exp. Med. 170: 577.

9. Lehn, M., Weisner, W.Y., Engelhorn, S, Gillis, S., and Remold, H.G. (1989). J. Immunol. 143: 3020.

10. Hart, P.H., Vitti, G.F., Burgess, D.R., Whitty, G.A., Piccoli, D.S., and Hamilton, J.H. (1989). Proc. Natl. Acad. Sci. USA. 86: 3803.

11. Chirgwin, J.M., Przybyca, A.E., MacDonald, R.J., and Rutter, W.J., (1979). Biochemistry 18: 5294-5299.

12. Strieter, R.M., Remick, D.G., Lynch, J.P., III, Genord, M., Raiford, C., Spengler, R., and Kunkel, S.L. (1989) Am. J. Respir. Cell Mol. Biol. 1: 57-63.

13. Scales, W.E., Chensue, S.W., Otterness, I., and Kunkel, S.L. (1989). J. Leukocyte Biol. 45: 416-421.

14. Standiford, T.J., Strieter, R.M., Chensue, S.W., Westwick, J., Kasahara, K., and Kunkel, S.L. J. Immunol. (in press). 